\title{
A Case discussion on Effect of Apamarga Pratsaraneeya Kshara in the management of Ardra Arshas w.s.r to Histopathological examination
}

\section{Case report}

\section{Avnish Pathak ${ }^{1 *}$, Dr.P.Hemantha kumar ${ }^{2}$}

1. Reader, Department of PG Studies in ShalyaTantra, 2. Professor \& HOD Department of PG Studies in ShalyaTantra, S.D.M.College of Ayurveda \& Hospital, Hassan, Karnataka -573201

\begin{abstract}
Kshara Karma is a one of the parasurgical procedure in Ayurveda. In this study Apamarga Pratisarneeya Kshara is used in Ardra Arshas (Internal Piles). After application of kshara size of Arshas and bleeding reduced completely and later on the wound created by Kshara Karma get fibrosed and prevents recurrence. A case report of 35 year old lady who presented with complaints of bleeding per rectum associated with constipation since last three months has been presented here.
\end{abstract}

Key Words: Kshara, Apamarga, Arshas

\section{Introduction:}

Haemorrhoids are one of the commonest diseases occurring in ano-rectal region. Its incidence increases with advancing age, at least $50 \%$ of the people over the age of 50 years have some degree of Haemorrhoidal symptoms. The disease haemorrhoids dealt under the concept of Arshas. Kshara Karma is one of the superior modality of parasurgical measures that has wide applicability in haemorrhoids.

Pratisaraneeya Kshara (caustic cauterization) is useful in wide, deep rooted, spreaded and elevated type of Arshas vis-a-

*Corresponding Author:

Avnish Pathak,

Reader, Department of PG Studies in ShalyaTantra,

S.D.M.College of Ayurveda \& Hospital, Hassan,

Karnataka- 573201.

E,mail -dravinishms@gmail.com vis II degree haemorrhoids. In this Case Apamarga Pratisarneeya Kshara is used and later on biopsy was taken from the site of application and Histopathological Examination was done to rule out the cause of recurrence.

After application of Apamarga Pratisarneeya Kshara it is being observed that there is no recurrence of hemorrhoids, to know the cause, that why there is no recurrence biopsy was taken from the site of application of kshara,followed by histopathological study and it is observed that The tissue becomes fibrosed and scar formation seen. The haemorrhoidal vein obliterates permanently and there is no recurrence of hemorrhoids.

The present ambulatory surgical procedures like Sclerotherapy, Rubber band ligation and infrared photo coagulation requires high cost sophisticated instruments. One of the great advantages of Pratisarneeya Kshara is that it can be safely and effectively used for patients of old age, 
late pregnancy and in persons unfit for surgery.

\section{Case report:}

A $35 y$ r old female presented with complaints of bleeding and mass per rectum associated with constipation. Bleeding was just before defecation. Three months ago patient was alright, gradually she developed the above complaint in the beginning bleeding per rectum was mild but later on it was going on increasing. There is no history of DM/HTN, the family history was not suggestive of same complaint to other member. On Digital Rectal Examinationthere was normal sphincter tonicity. On Proctoscopy - Internal piles are visualized at 11 'o clock position.

The classical Lakshanas of Ardra Arshas like Neela, Tuni, Visarpani, shookaJivha Kledavat, Panasa phala (1) like etc. were observed Routine hematology investigations (TC, DC, Hb, ESR, RBS) and urine investigations were within normal limits. As Susrutha describred the indication of Pratisarneeya Kshara are Mrudu, Prasrut, Avagada and slightly elevated piles. The patients were laid down on table in lithotomy position and Slit proctoscope lubricated with Lox - 2\% (Lignocaine Hydrochloride gel) a local anesthetics, was slowly introduced in anal canal fully. The hemorrhoid site was identified and cleaned with cotton swab. Packing was done to the surrounding area and kshara is applied only to the pile mass for hundred matra kala (approx 2 mins) and in this time period the pile mass became in black color (like Jambu Phala). Soon after this Biopsy specimen is taken and sent for histopathological examination. Later on after one week the slough of the region sent for HPE. Same procedure is repeated after 15 days. Later on in the third month biopsy was repeated and it is suggestive of Fibrosis of that area.
Discussion on the effect of treatment: Mode of Action of Pratisaraneeya Kshara in Internal piles:

PratisaraneeyaKshara acts on haemorrhoids in two ways (Figure: 1)

(1) It cauterizes the pile mass directly because of its corrosive nature.

(2) It coagulates protein in haemorrhoidal plexus.

The coagulation of protein leads to disintegration of haemoglobin into haem and globin. Synergy of these actions results in decreasing the size of the pile mass. Further, necrosis of the tissue in the haemorrhoidal vein will occur. This necrosed tissue slough out as blackish brown discharge for 3 to 7 days. The haem present in the slough gives the discharge its color. (3)

\section{Conclusion:}

The tissue becomes fibrosed and scar formation seen. The haemorrhoidal vein obliterates permanently and there is no recurrence of hemorrhoids.

\section{References:}

1. Vaidya Yadavji Trikamjiacharya:Sushruta samhitha with Dalhanacharya

Nibhandhasangraha and Gayadasacharya Nyaychandrika Panjika commentary edited by Krishnadas Academy, Varanasi, $7^{\text {th }}$ Edition 2002, Nidanasthana 2/14, Page - 273.

2. Vaidya Yadavji Trikamjiacharya:Sushruta samhitha with Dalhanacharya Nibhandhasangraha and Gayadasacharya Nyaychandrika Panjika commentary edited by Krishnadas Academy, Varanasi, $7^{\text {th }}$ Edition 2002, Chikitsasthana 6/3-4, Page -430 . 


\section{International Journal of Ayurvedic Medicine, 2012, 3(4), 193-195}

3. Dr.P.Hemantha Kumar, P.V.Ramesh Babu and M.Sahu, Effect of Pratisaraniya Kshara in the Management of Haemorrhoids Journal of National Integrated
Medical Association, June, 1998, Vol.XLno-6 Page no 9 to11, ISSN0377-0621

Figure: 1

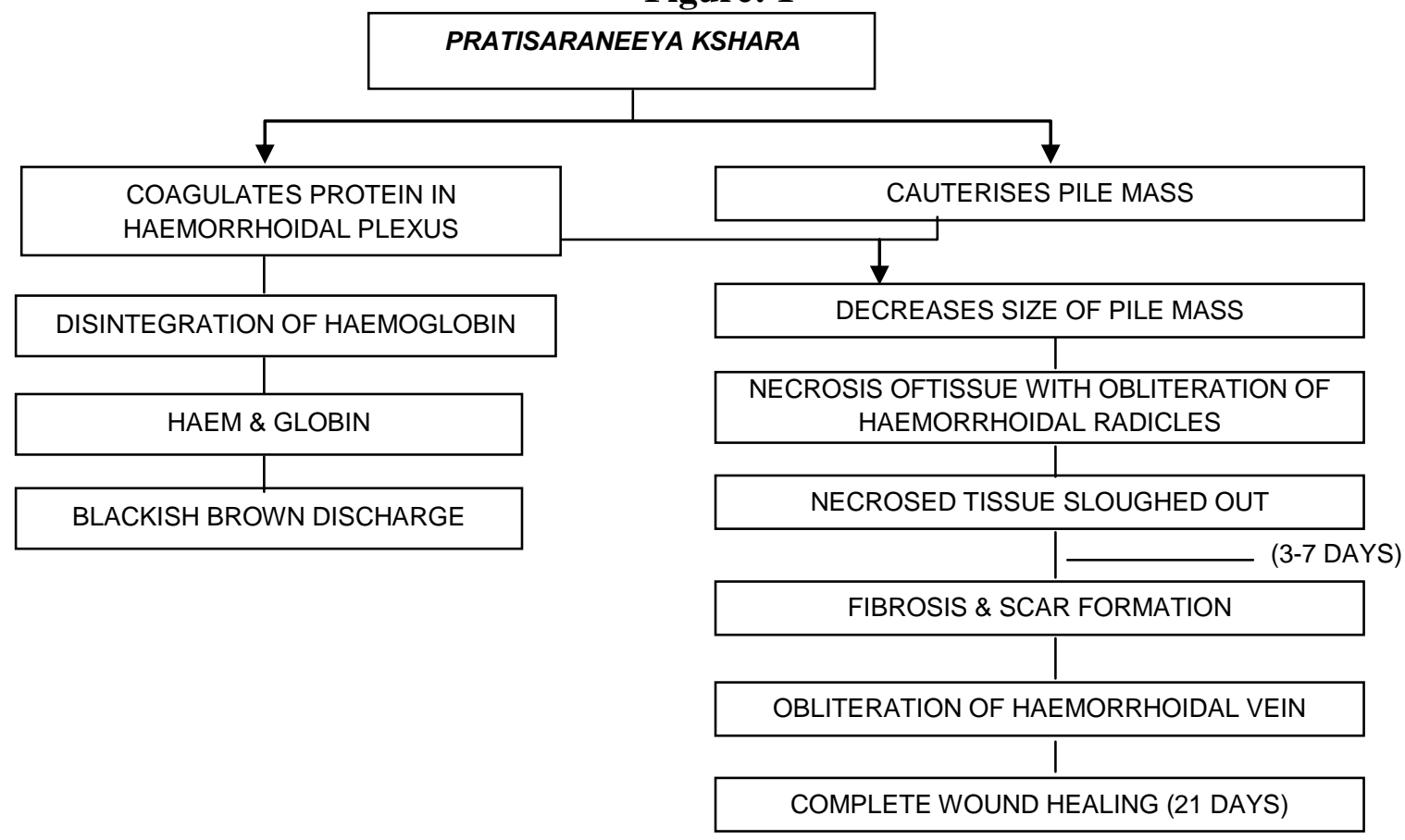

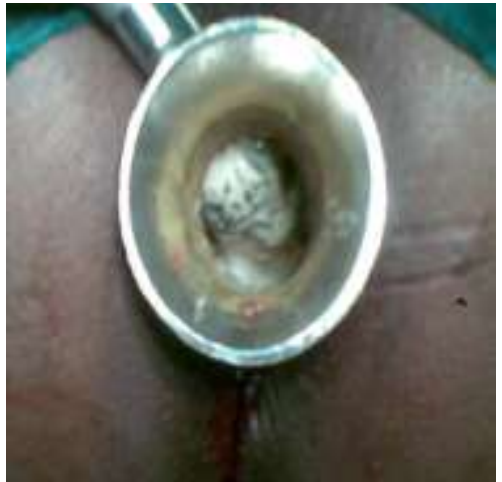

Photo 1: Application of Pratisarneeya Kshara

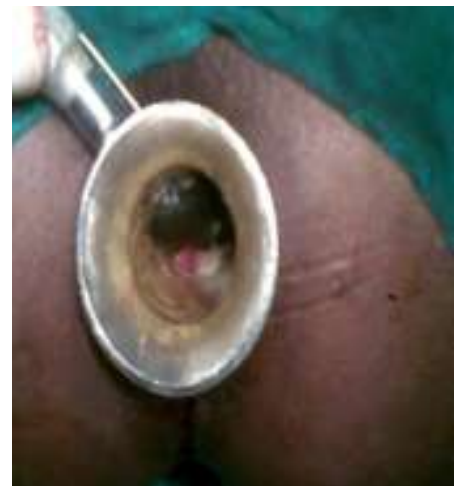

Photo 2: After 2 minutes (like Jambuphala)

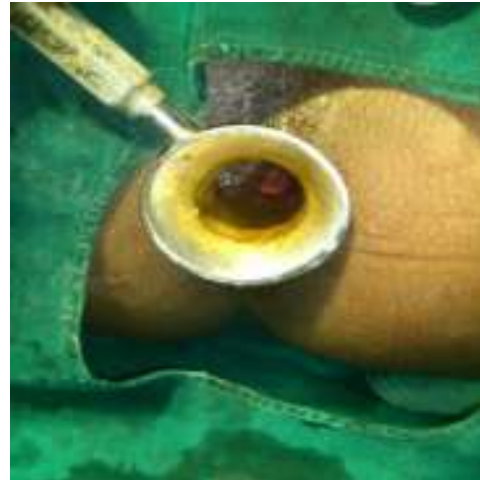

Photo 3: Fibrosis at the site of application 